Marquette University

e-Publications@Marquette

$10-4-2002$

\title{
Kinetic and Structural Characterization of Manganese(II)-Loaded Methionyl Aminopeptidases
}

\author{
Ventris M. D'Souza \\ Utah State University \\ Sabina I. Swierczek \\ Utah State University \\ Nathaniel J. Cosper \\ University of Georgia \\ Lu Meng \\ Utah State University \\ Shane Ruebush \\ Utah State University
}

See next page for additional authors

Follow this and additional works at: https://epublications.marquette.edu/chem_fac

Part of the Chemistry Commons

\section{Recommended Citation}

D'Souza, Ventris M.; Swierczek, Sabina I.; Cosper, Nathaniel J.; Meng, Lu; Ruebush, Shane; Copik, Alicja J.; Scott, Robert A.; and Holz, Richard C., "Kinetic and Structural Characterization of Manganese(II)-Loaded Methionyl Aminopeptidases" (2002). Chemistry Faculty Research and Publications. 309.

https://epublications.marquette.edu/chem_fac/309 


\section{Authors}

Ventris M. D'Souza, Sabina I. Swierczek, Nathaniel J. Cosper, Lu Meng, Shane Ruebush, Alicja J. Copik, Robert A. Scott, and Richard C. Holz 
Marquette University

e-Publications@Marquette

\section{Chemistry Faculty Research and Publications/College of Arts and Sciences}

This paper is NOT THE PUBLISHED VERSION; but the author's final, peer-reviewed manuscript. The published version may be accessed by following the link in the citation below.

Biochemistry, Vol. 41, No. 43 (October 4, 2002): 13096-13105. DOI. This article is (C) American Chemical Society Publications and permission has been granted for this version to appear in $\underline{\mathrm{e}}-$ Publications@Marquette. American Chemical Society Publications does not grant permission for this article to be further copied/distributed or hosted elsewhere without the express permission from American Chemical Society Publications.

\section{Kinetic and Structural Characterization of Manganese(II)-Loaded Methionyl Aminopeptidases}

Ventris M. D'souza

Department of Chemistry and Biochemistry, Utah State University, Logan, Utah Sabina I. Swierczek

Department of Chemistry and Biochemistry, Utah State University, Logan, Utah Nathaniel J. Cosper

Department of Chemistry, University of Georgia, Athens, Georgia

Lu Meng

Department of Chemistry and Biochemistry, Utah State University, Logan, Utah Shane Ruebush

Department of Chemistry and Biochemistry, Utah State University, Logan, Utah Alicja J. Copik

Department of Chemistry and Biochemistry, Utah State University, Logan, Utah 


\title{
Robert A. Scott
}

Department of Chemistry, University of Georgia, Athens, Georgia

Richard C. Holz

Department of Chemistry and Biochemistry, Utah State University, Logan, Utah

\section{SUBJECTS:}

Peptides and proteins, Metals, Monomers, lons, Mathematical methods

\begin{abstract}
Manganese(II) activation of the methionyl aminopeptidases from Escherichia coli (EcMetAP-I) and the hyperthermophilic archaeon Pyrococcus furiosus (PfMetAP-II) was investigated. Maximum catalytic activity for both enzymes was obtained with 1 equiv of $\mathrm{Mn}(\mathrm{II})$, and the dissociation constants $\left(K_{\mathrm{d}}\right)$ for the first metal binding site were found to be $6 \pm 0.5$ and $1 \pm 0.5 \mu \mathrm{M}$ for EcMetAP-I and PfMetAP-II, respectively. These $K_{\mathrm{d}}$ values were verified by isothermal titration calorimetry (ITC) and found to be $3.0 \pm 0.2$ and 1.4 $\pm 0.2 \mu \mathrm{M}$ for EcMetAP-I and PfMetAP-II, respectively. The hydrolysis of MGMM was measured in triplicate between 25 and $85{ }^{\circ} \mathrm{C}$ at eight substrate concentrations ranging from 2 to $20 \mathrm{mM}$ for PfMetAP-II. Both specific activity and $K_{\mathrm{m}}$ values increased with increasing temperature. An Arrhenius plot was constructed from the $k_{\text {cat }}$ values and was found to be linear over the temperature range $25-85^{\circ} \mathrm{C}$. The activation energy for the $\mathrm{Mn}(\mathrm{II})$-loaded PfMetAP-II hydrolysis of MGMM was found to be $25.7 \mathrm{~kJ} / \mathrm{mol}$ while the remaining thermodynamic parameters calculated at $25^{\circ} \mathrm{C}$ are $\Delta G^{*}=50.1 \mathrm{~kJ} / \mathrm{mol}, \Delta H^{\neq}=23.2 \mathrm{~kJ} / \mathrm{mol}$, and $\Delta S^{\neq}=-90.2 \mathrm{~J} \cdot \mathrm{mol}^{-1} \cdot \mathrm{K}^{-1}$.
\end{abstract}

Methionyl aminopeptidases (MetAP's) ${ }^{1}$ represent a unique class of proteases that are capable of the hydrolytic removal of $\mathrm{N}$-terminal methionine residues from nascent polypeptide chains (1-4). The biosynthesis of all eukaryotic proteins present in the cytosol is initiated with methionine, while in prokaryotes, mitochondria, and chloroplasts, the initiator residue is an $N$-formylmethionine group. The $N$-formyl group is removed from proteins in prokaryotes and eukaryotic organelles by a deformylase, leaving a methionine residue at the amino terminus (2). Subsequently, the $\mathrm{N}$-terminal methionine is cleaved by MetAP. While the rationale for the removal of the initiator methionine remains unclear, several explanations have been proposed (5). Some involve the facilitation of further processing after excision of $\mathrm{N}$-terminal groups such as the removal of signal sequences, proteolytic cleavage to generate shorter peptides, and the covalent attachment of residues and blocking groups such as acetyl and myristoyl groups (4). The structure of the mature $\mathrm{N}$-terminus plays a role in $\mathrm{N}$-directed degradation pathways $(3,6)$ and in targeting to cellular membranes (1-4). MetAP's are therefore one of the key cellular enzymes involved in protein maturation. The physiological importance of MetAP activity is underscored by the lethality of the deletion of the genes in Escherichia coli, Salmonella typhimurium, and Saccharomyces cerevisiae (7-9). For this reason, MetAP's are under intense scrutiny as potential targets for antibacterial and antifungal drugs.

MetAP's are organized into two classes (types I and II) on the basis of the absence or presence of an extra 62 amino acid sequence (of unknown function) inserted near the catalytic domain. The type I MetAP from $E$. coli (EcMetAP-I) and the type II MetAP's from Homo sapiens (HsMetAP-II) and Pyrococcus furiosus (PfMetAP-II) have been crystallographically characterized (10-13). All of these MetAP's have identical catalytic domains that contain a bis( $\mu$-carboxylato)( $\mu$-aquo/hydroxo)dicobalt core with an additional carboxylate residue at each metal site and a single histidine residue bound to one of the two metal ions (10-13). Each structure also revealed the presence of two solvent molecules in the active site, one of which bridges the two Co(II) ions while the second 
acts as a terminal ligand coordinated to the non-histidine-ligated Co(II) ion. In all three structures, both Co(II) ions appear to reside in a trigonal-bipyramidal coordination environment (10-13). Since all of the catalytic domain residues are completely conserved for both type I and type II MetAP's, all MetAP's likely bind divalent metal ions in a similar fashion. This suggestion was recently verified by comparison of the divalent metal binding properties of EcMetAP-I and PfMetAP-II $(14,15)$.

Until recently, all MetAP's studied had been reported to be Co(II)-dependent metalloproteases $(16,17)$. While the identity of the in vivo metal ion has not been established for any MetAP, Fe(II) and Mn(II) were suggested as potential candidates on the basis of whole cell metal analyses for ECMetAP-I (18). Further studies on Co(II) and Fe(II) binding to EcMetAP-I and PfMetAP-II led to the proposal that MetAP's function as mononuclear enzymes in vitro $(14,15)$. Structural evidence for a mononuclear Co(II) or Fe(II) active site in MetAP's was recently obtained by use of extended X-ray absorption fine structure (EXAFS) (19). The high-affinity or catalytically relevant metal binding site was assigned as the histidine-containing side of the active site on the basis of EXAFS and ${ }^{1} \mathrm{H}$ NMR data (15). Mn(II) was also shown to activate EcMetAP-I, but no kinetic or structural information has been reported. Herein, we report the catalytic and structural properties of the $\mathrm{Mn}$ (II)-loaded forms of both EcMetAP-I and PfMetAP-II. On the basis of kinetic, thermodynamic, and EXAFS data, Mn(II) is shown to bind to both type I and type II MetAP's in a fashion similar to that of Co(II) and Fe(II). Because PfMetAP-II and HsMetAP-II are 39\% identical while PfMetAP-II and EcMetAP-I are 33\% identical, the structural and mechanistic data obtained for the Mn(II)-loaded EcMetAP-I and PfMetAP-II can be extrapolated to HsMetAP-II. The catalytic and structural similarities and differences between $\mathrm{Co}(\mathrm{II})$ - and $\mathrm{Mn}$ (II)-loaded MetAP's are also discussed.

\section{Materials and Methods}

\section{Purification of MetAP Enzymes.}

All chemicals used in this study were purchased commercially and were of the highest quality available.

Recombinant EcMetAP-I was expressed and purified as an apoenzyme, as previously described, from a stock culture kindly provided by Drs. Brian W. Matthews and W. Todd Lowther $(18,20)$. The as purified EcMetAP-I exhibited a single band on SDS-PAGE. Protein concentrations were obtained spectrophotometrically at $280 \mathrm{~nm}$ using an extinction coefficient $\varepsilon_{280}$ of $16445 \mathrm{M}^{-1} \mathrm{~cm}^{-1}(18,20)$. Apo-EcMetAP-I was washed free of methionine using Chelex-treated methionine-free buffer ( $25 \mathrm{mM}$ Hepes, $\mathrm{pH} 7.5,150 \mathrm{mM} \mathrm{KCl}$ ) and concentrated by microfiltration using a Centrocon-10 (Amicon, Beverly, MA) prior to all kinetic assays. Individual aliquots of apoEcMetAP-I were routinely stored at $-80^{\circ} \mathrm{C}$ or in liquid nitrogen until needed.

PfMetAP-II was purified as previously reported (14). Purified PfMetAP-II exhibited a single band on SDS-PAGE with a $M_{r}$ of 32800 . Protein concentrations were estimated from the absorbance at $280 \mathrm{~nm}$ using an extinction coefficient of $21650 \mathrm{M}^{-1} \mathrm{~cm}^{-1}$. Metal-free PfMetAP-II was prepared by concentrating the as purified PfMetAP-II to a volume of $\sim 5 \mathrm{~mL}$ after which EDTA was added to a final concentration of $10 \mathrm{mM}$. The resulting protein solution was dialyzed against $25 \mathrm{mM}$ Hepes buffer ( $2 \mathrm{~L}, \mathrm{pH} 7.5$ ) containing $10 \mathrm{mM}$ EDTA and $150 \mathrm{mM} \mathrm{KCl}$ at $4{ }^{\circ} \mathrm{C}$ for 2 days with two buffer changes per day. The protein solution was then dialyzed against chelexed (Chelex-100 column) $25 \mathrm{mM}$ Hepes buffer ( $2 \mathrm{~L}, \mathrm{pH}$ 7.5) containing $150 \mathrm{mM} \mathrm{KCl}$ for 3 days against two buffer changes per day. The resulting PfMetAP-II was inactive and was found to contain no detectable metal ions via inductively coupled plasma-atomic emission spectrometry (ICP-AES). This enzyme deemed "apo-PfMetAP-II" was stored at $-80{ }^{\circ} \mathrm{C}$.

\section{Metal Content Measurements.}

EcMetAP-I and PfMetAP-II samples used for metal analysis were typically $30 \mu \mathrm{M}$. Apo-EcMetAP-I or apoPfMetAP-II samples were incubated under anaerobic conditions with $\mathrm{Mn}$ (II) $\left(\mathrm{MnCl}_{2}=99.999 \%\right.$; Strem Chemicals, Newburyport, MA, or Aldrich) for 30 or 90 min, respectively, prior to exhaustive dialysis under anaerobic 
conditions against Chelex-treated buffer as previously reported $(15,18)$. Metal analyses were performed using ICP-AES.

\section{Enzymatic Assay of MetAP's.}

All enzymatic assays were performed under strict anaerobic conditions in an inert atmosphere glovebox (Coy) with a dry bath incubator to maintain the temperature. Catalytic activities were determined with an error of $\pm 5 \%$. Enzyme activities for both EcMetAP-I and PfMetAP-II were determined in $25 \mathrm{mM}$ Hepes buffer, $\mathrm{pH} 7.5$, containing $150 \mathrm{mM} \mathrm{KCl}$ with the tri- or tetrapeptide substrates MAS or MGMM, respectively. The amount of product formation was determined by high-performance liquid chromatography (HPLC, Shimadzu LC-10A classVP5). A typical assay involved the addition of $4 \mu \mathrm{L}$ of metal-loaded MetAP to a $16 \mu \mathrm{L}$ substrate-buffer mixture at $30{ }^{\circ} \mathrm{C}$ for $1 \mathrm{~min}$. The reaction was quenched by the addition of $20 \mu \mathrm{L}$ of $1 \%$ trifluoroacetic acid solution (TFA). Elution of the product was monitored at $215 \mathrm{~nm}$ following separation on a C8 HPLC column (Phenomenex, Luna; $5 \mu \mathrm{m}, 4.6 \times 25 \mathrm{~cm}$ ), as previously described $(15,18)$. The kinetic parameters $v$ (velocity) and $K_{\mathrm{m}}$ (Michaelis constant) were determined in triplicate. Enzyme activities are expressed as units per milligram, where one unit is defined as the amount of enzyme that releases $1 \mu \mathrm{mol}$ of product in $1 \mathrm{~min}$ at $30^{\circ} \mathrm{C}$. The metal binding titration and temperature dependence reactions were carried out using the same conditions as determined for the kinetic constants.

\section{Isothermal Titration Calorimetry.}

Isothermal titration calorimetry (ITC) measurements were carried out on a MicroCal OMEGA ultrasensitive titration calorimeter. The titrant $\left(\mathrm{MnCl}_{2}=99.999 \%\right.$; Strem Chemicals, Newburyport, $\mathrm{MA}$, or Aldrich) and sample solutions (apo-EcMetAP-I or apo-PfMetAP-II) were prepared in chelexed $25 \mathrm{mM}$ Hepes buffer at pH 7.5 containing $150 \mathrm{mM} \mathrm{KCl}$. Stock buffer solutions were thoroughly degassed before each titration. The enzyme solution $(70 \mu \mathrm{M})$ was placed in the calorimeter cell and stirred at $200 \mathrm{rpm}$ to ensure rapid mixing. Typically, $3 \mu \mathrm{L}$ of titrant was delivered over $7.6 \mathrm{~s}$ with a $5 \mathrm{~min}$ interval between injections to allow for complete equilibration. Each titration was continued until 4.5-6 equiv of $\mathrm{Mn}$ (II) had been added to ensure that no additional complexes were formed in excess titrant. A background titration, consisting of the identical titrant solution but only the buffer solution in the sample cell, was subtracted from each experimental titration to account for heat of dilution. The data were analyzed with a two-site binding model by the Windows-based Origin software package supplied by MicroCal.

\section{X-ray Absorption Spectroscopy of EcMetAP-I.}

EXAFS samples of EcMetAP-I (1 mM) with 1 or 2 equiv of added Mn(II) (i.e., [Mn(II)_(EcMetAP-I)] and [Mn(II)Mn(II)(EcMetAP-I)]) were prepared in chelexed $25 \mathrm{mM}$ Hepes buffer at $\mathrm{pH} 7.5$ containing $150 \mathrm{mM} \mathrm{KCl}$ with $5 \%$ glycerol. For Mn(II)-loaded EcMetAP-I, EXAFS samples were frozen in polycarbonate cuvettes, $24 \times 3 \times 1$ $\mathrm{mm}$, with a $0.025 \mathrm{~mm}$ Mylar window covering one $24 \times 3 \mathrm{~mm}$ face. XAS data were collected at the Stanford Synchrotron Radiation Laboratory (SSRL) with the SPEAR storage ring operating at $3.0 \mathrm{GeV}$ (Table 1). The edge regions for multiple scans obtained on the same sample were compared to ensure that the sample was not damaged by exposure to X-ray radiation. EXAFS analysis was performed using EXAFSPAK software (wwwssrl.slac.stanford.edu/exafspak.html) according to standard procedures (21). Multiple-scattering analysis was performed as described previously (19). Both single- and multiple-scattering paths of $4.5 \AA$ from the $\mathrm{Mn}$ atom were used to identify and quantify imidazole coordination due to histidine. Multiple-scattering models, calculated using FEFF v7 (23), were based on hexaimidazole manganese(II) chloride tetrahydrate (24). Possible coordination numbers of histidyl imidazole ligands were chosen from fits that yielded chemically and physically reasonable Debye-Waller factors for the outer-shell atoms, since goodness-of-fit values $\left(f^{\prime}\right)$ were relatively insensitive to these coordination numbers. 
Table 1: X-ray Absorption Spectroscopic Data Collection

\begin{tabular}{|l|l|}
\hline & Mn EXAFS \\
\hline SR facility & SSRL \\
\hline beamline & $7-3$ \\
\hline current in storage ring, $\mathrm{mA}$ & $80-100$ \\
\hline monochromator crystal & Si[220] \\
\hline detection method & fluorescence \\
\hline detector type & solid state array ${ }^{a}$ \\
\hline scan length, min & 28 \\
\hline scans in average & 16 \\
\hline temperature, $\mathrm{K}$ & 10 \\
\hline energy standard & $\mathrm{Mn}$ foil, first inflection \\
\hline energy calibration, eV & 6539 \\
\hline$E_{0}$, eV & 6545 \\
\hline preedge background & \\
\hline energy range, eV & $6215-6500$ \\
\hline Gaussian center, eV & 5898 \\
\hline width, eV & 800 \\
\hline spline background & \\
\hline energy range, eV & $6545-6730(4)$ \\
\hline (polynomial order) & $6730-6915(4)$ \\
\hline
\end{tabular}

${ }^{a}$ The 13-element Ge solid-state X-ray fluorescence detector at SSRL is provided by the NIH Biotechnology Research Resource.

\section{Results}

Time Dependence of Mn(II) Binding and Mn(II) Content of EcMetAP-I and PfMetAP-II. The time required to fully activate either EcMetAP-I or PfMetAP-II with Mn(II) ions was measured (Figure 1). For EcMetAP-I, no change in the specific activity was observed even with incubation times as short as $10 \mathrm{~min}$. However, for PfMetAP-II, fully active enzyme was not obtained until after $90 \mathrm{~min}$ had passed. Therefore, all kinetic and metal binding measurements for PfMetAP-I were made after a 90 min incubation period.

Interestingly, $\mathrm{Fe}(\mathrm{II})$ and $\mathrm{Co}(\mathrm{II})$ activate PfMetAP-II in $10 \mathrm{~min}$, similar to EcMetAP-I. The number of tightly bound $\mathrm{Mn}(\mathrm{II})$ ions was determined for EcMetAP-I and PfMetAP-II by ICP-AES analysis. MetAP samples ( $30 \mu \mathrm{M})$, to which 2-30 equiv of $\mathrm{Mn}(\mathrm{II})$ was added, were dialyzed extensively for $3 \mathrm{~h}$ at $4{ }^{\circ} \mathrm{C}$ against metal-free Hepes buffer. Upon ICP-AES analysis 1.3 and $1.5 \pm 0.1$ equiv of manganese was found coordinated to ECMetAP-I and PfMetAP-II, respectively. These data suggest that one $\mathrm{Mn}(\mathrm{II})$ ion is tightly bound to both EcMetAP-I and PfMetAP-II at these enzyme concentrations, while the second metal ion is partially labile on the time scale of the buffer exchange ( 3 $\left.\mathrm{h}, 4^{\circ} \mathrm{C}\right)$. 


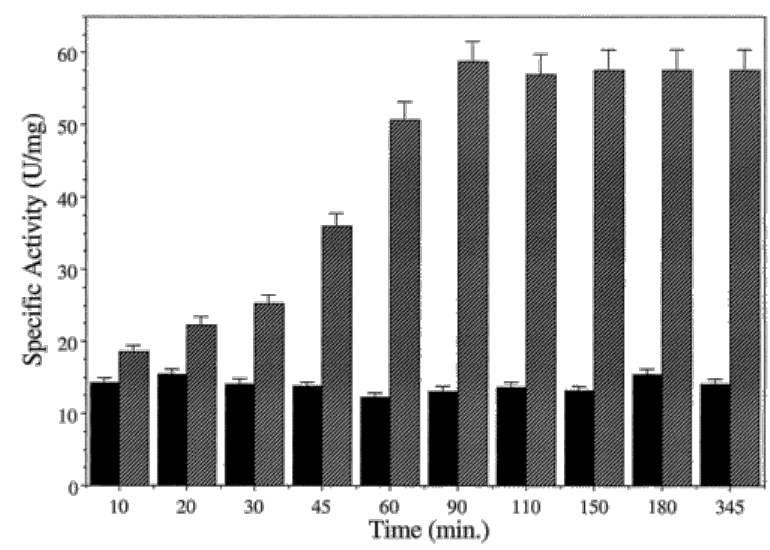

Figure 1 Plot of specific activity (units/mg) vs time. The solid bars represent activities obtained for Mn(II)loaded EcMetAP-I, and the shaded bars are activity levels observed for Mn(II)-loaded PfMetAP-II. All activity measurements were performed at $30^{\circ} \mathrm{C}$, and all stock solutions were prepared anaerobically in $25 \mathrm{mM}$ Hepes buffer at pH 7.5 containing $150 \mathrm{mM} \mathrm{KCl}$. Each point represents the mean of three independent measurements.

\section{Determination of the $\mathrm{K}_{m}$ Values for MAS and MGMM.}

The strength of MAS and MGMM binding to the active site of Mn(II)-loaded EcMetAP-I and PfMetAP-II was determined (Table 2). The initial rates of hydrolysis of MAS or MGMM by Mn(II)-loaded EcMetAP-I and PfMetAPII were monitored as a function of AS or GMM concentration, respectively, in $25 \mathrm{mM}$ Hepes buffer, pH 7.5, and $150 \mathrm{mM} \mathrm{KCl}$. Triplicate activity assay determinations at six concentrations of MAS or MGMM (0-9 mM) were made and the results plotted as $1 / v$ vs $1 /[\mathrm{S}]$. From fits of these data, the Michaelis constant $\left(K_{\mathrm{m}}\right)$ for MAS and MGMM binding to Mn(II)-loaded ECMetAP-I and PfMetAP-II was determined (Table 2). For Mn(II)loaded ECMetAP-I, no catalytic turnover was observed in the presence of MAS even at substrate concentrations of $20 \mathrm{mM}$ while $\mathrm{Mn}(\mathrm{II})$-loaded PfMetAP-II bound MAS weakly $\left(K_{\mathrm{m}}=5.7 \mathrm{mM}\right)$. Similarly, $k_{\text {cat }}$ values were determined for Mn(II)-loaded PfMetAP-II toward both substrates and EcMetAP-I toward MGMM. A 16-fold decrease in $k_{\text {cat }}$ was observed for $\mathrm{Mn}$ (II)-loaded PfMetAP-II toward MAS vs MGMM. This decrease in $k_{\text {cat }}$ results in a decrease in the catalytic efficiency $\left(k_{\text {cat }} / K_{\mathrm{m}}\right)$ of over 60 -fold. Interestingly, at $30^{\circ} \mathrm{C} \mathrm{Mn}(\mathrm{II})$-loaded EcMetAP-I exhibits a turnover rate that is more than 13 times faster than $\mathrm{Mn}(\mathrm{II})$-loaded PfMetAP-II toward MGMM. Since the $K_{\mathrm{m}}$ values are similar for the two enzymes toward MGMM, Mn(II)-loaded EcMetAP-I is a better catalyst by 16-fold. On the other hand, at $85^{\circ} \mathrm{C}$, the optimum temperature for catalytic activity for Mn(II)-loaded PfMetAP$\mathrm{II}$, the $k_{\text {cat }}$ value increases 5 -fold to $164 \mathrm{~s}^{-1}$, but the $K_{\mathrm{m}}$ value also increases over 6 -fold to $10.3 \mathrm{mM}$, resulting in a catalytic efficiency of $15900 \mathrm{M}^{-1} \mathrm{~s}^{-1}$, a 1.3-fold decrease.

Table 2: Kinetic Constants for Mn(II)-Loaded EcMetAP-I and PfMetAP-II for Various Substrates at $30^{\circ} \mathrm{C}$ and $\mathrm{pH}$ 7.5

\begin{tabular}{|l|l|l|l|}
\hline enzyme & kinetic constants & MGMM & MAS \\
\hline Mn-EcMetAP-I & $K_{\mathrm{m}}(\mathrm{mM})$ & $1.3 \pm 0.2$ & $\mathrm{NR}^{a}$ \\
\hline & $k_{\text {cat }}\left(\mathrm{s}^{-1}\right)$ & 4.6 & \\
\hline & $k_{\text {cat }} / K_{\mathrm{m}}\left(\mathrm{M}^{-1} \mathrm{~s}^{-1}\right)$ & 3500 & \\
\hline & $V_{\max }\left(\mathrm{nmol} \mathrm{min}{ }^{-1}\right)$ & $12.9 \pm 0.4$ & \\
\hline & $\mathrm{SA}(\mathrm{units} / \mathrm{mg})$ & $13 \pm 2$ & \\
\hline Mn-PfMetAP-II & $K_{\mathrm{m}}(\mathrm{mM})$ & $1.6 \pm 0.2$ & $5.7 \pm 0.2$ \\
\hline & $k_{\text {cat }}\left(\mathrm{s}^{-1}\right)$ & $32 \pm 4$ & 1.96 \\
\hline & $k_{\text {cat }} / K_{\mathrm{m}}\left(\mathrm{M}^{-1} \mathrm{~s}^{-1}\right)$ & 20800 & 344 \\
\hline & $V_{\max }\left(\mathrm{nmol} \mathrm{min}{ }^{-1}\right)$ & $155 \pm 5$ & $2.4+0.3$ \\
\hline & $\mathrm{SA}(\mathrm{units} / \mathrm{mg})$ & $59 \pm 5$ & $3.6 \pm 0.8$ \\
\hline
\end{tabular}

${ }^{a}$ No reaction was detected. 


\section{Activity as a Function of Manganese(II) Concentration.}

The extent of hydrolytic activity exhibited by EcMetAP-I and PfMetAP-II was determined as a function of Mn(II) concentration. Apo-EcMetAP-I and apo-PfMetAP-II (both at $8.3 \mu \mathrm{M}$ ) were incubated with varying amounts of $\mathrm{Mn}(\mathrm{II})$, and the level of catalytic activity was determined (Figure 2). Upon the addition of $\mathrm{Mn}(\mathrm{II})$ to apo-EcMetAPI or apo-PfMetAP-II under anaerobic conditions, the specific activity increased as a function of metal ion concentration up to approximately 2 equiv of $\mathrm{Mn}$ (II) for both EcMetAP-I and PfMetAP-II (Figure 2, inset). Further additions of up to 5 equiv of $\mathrm{Mn}$ (II) to either enzyme had little or no effect on the observed enzymatic activity. Interestingly, upon the addition of $\mathrm{Mn}$ (II) up to $>830 \mu \mathrm{M}$ ( 100 equiv) the activity level of both enzymes remained constant and continued to remain constant even up to 400 equiv of added Mn(II) (Figure 2).

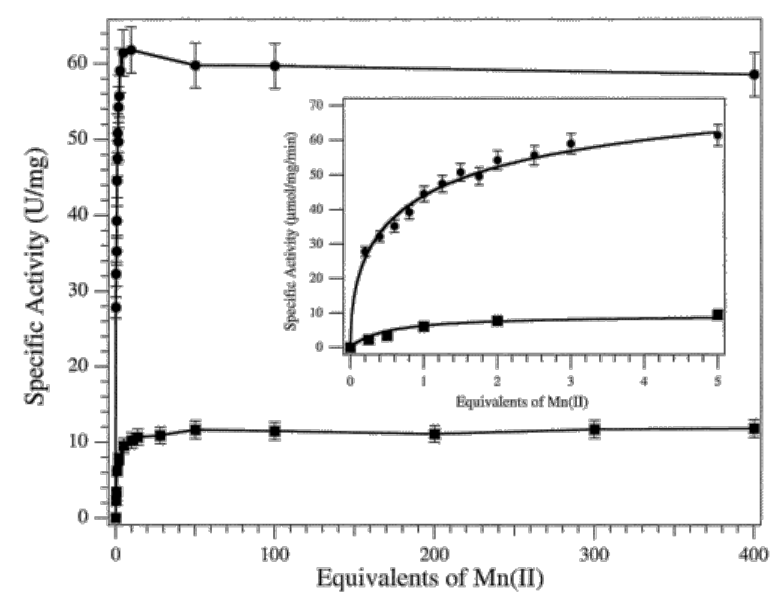

Figure 2 Plot of specific activity vs $\mathrm{Mn}(\mathrm{II})$ concentration (inset: expanded view of the $0-10$ equiv region). All activity measurements were performed at $30^{\circ} \mathrm{C}$, and all stock solutions were prepared anaerobically in $25 \mathrm{mM}$ Hepes buffer at $\mathrm{pH} 7.5$ containing $150 \mathrm{mM} \mathrm{KCl}$. Each point represents the mean of three independent measurements.

The activity titration data for Mn(II) binding to EcMetAP-I and PfMetAP-II (Figure 3) were fit to the equation (24):

$r=p C_{s} /\left(K_{d}+C_{s}\right)(1)$

where $p$ is the number of sites for which interaction with $M(I I)$ is governed by the intrinsic dissociation constant $K_{\mathrm{d}}$ and $r$ is the binding function which was calculated as previously described (14). A value for the dissociation constants $\left(K_{\mathrm{d}}\right)$ was obtained by fitting these data via an iterative process that allowed both $K_{\mathrm{d}}$ and $p$ to vary (Figure 3 ). The best fits obtained provided $p$ values of 1 for both EcMetAP-I and PfMetAP-II with $K_{\mathrm{d}}$ values of $6 \pm 0.5$ and $1 \pm 0.5 \mu \mathrm{M}$ for $\mathrm{Mn}$ (II)-loaded EcMetAP-I and PfMetAP-II, respectively. Attempts to fit these data with a $p$ value of 2 provided no improvements in the overall goodness of the fit. 


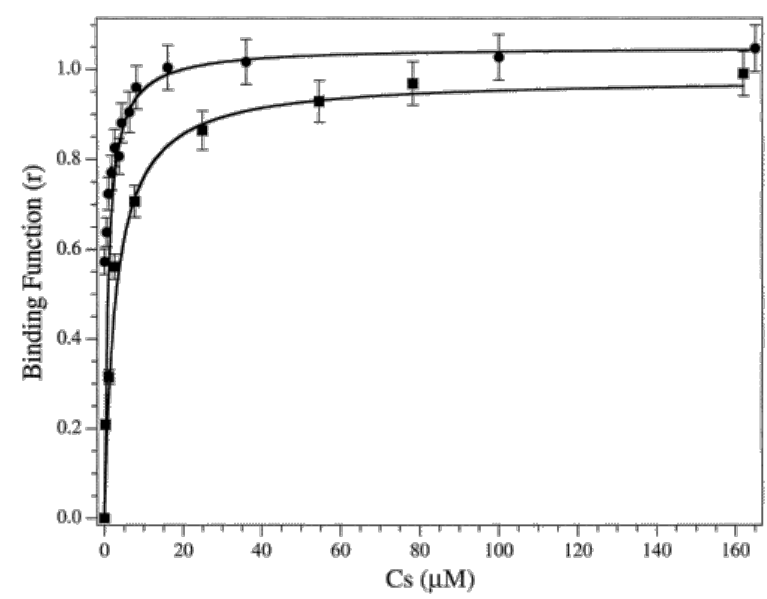

Figure 3 Plot of binding function, $r$, vs $C_{s}$ (the concentration of free metal ions in solution) for $\mathrm{Mn}$ (II) titration into PfMetAP-II (·) and ECMetAP-I (-). The solid lines represent fits of the activity data to eq 1 . Enzyme concentrations were $8.3 \mu \mathrm{M}$, and the measurements were made at $30^{\circ} \mathrm{C}$ in $25 \mathrm{mM}$ Hepes buffer, $\mathrm{pH} 7.5$, and $150 \mathrm{mM} \mathrm{KCl}$.

\section{Isothermal Titration Calorimetry.}

Isothermal titration calorimetry (ITC) measurements were carried out on a MicroCal OMEGA ultrasensitive titration calorimeter at $20 \pm 0.2^{\circ} \mathrm{C}$ for EcMetAP-I and $30 \pm 0.2^{\circ} \mathrm{C}$ for PfMetAP-II (Figures 4A and 5A). Association constants $\left(K_{\mathrm{b}}\right)$ were obtained by fitting these data, after subtraction of the background heat of dilution, via an iterative process using the Origin software package. This software package uses a nonlinear least-squares algorithm which allows the concentrations of the titrant and the sample to be fit to the heat flow per injection to an equilibrium binding equation for two sets of noninteracting sites. The $K_{\mathrm{b}}$ value, the enzyme-metal stoichiometry $(n)$, and the change in enthalpy $\left(\Delta H^{\circ}\right)$ were allowed to vary during the fitting process. The best fits obtained for both EcMetAP-I and PfMetAP-II provided an overall $n$ value of 3 for three noninteracting sites (Figures $4 \mathrm{~B}$ and $5 \mathrm{~B}$ ). Attempts to fit these data with $n$ values of 1 or 2 provided poor fits as did fits in which the $n$ value was 3 but the binding process was considered cooperative. For EcMetAP-I, a $K_{d}$ value of $3.0 \pm 0.2 \mu \mathrm{M}$ was observed, and two $K_{d}$ values of $4400 \pm 300 \mu \mathrm{M}$ were also obtained. On the other hand, a $K_{d}$ value of $1.4 \pm$ $0.2 \mu \mathrm{M}$ was obtained for PfMetAP-II, and two $K_{d}$ values of $500 \pm 50 \mu \mathrm{M}$ were also obtained. These data correspond to individual binding events of three $\mathrm{Mn}(\mathrm{II})$ ions to the EcMetAP-I and PfMetAP-II enzymes. 


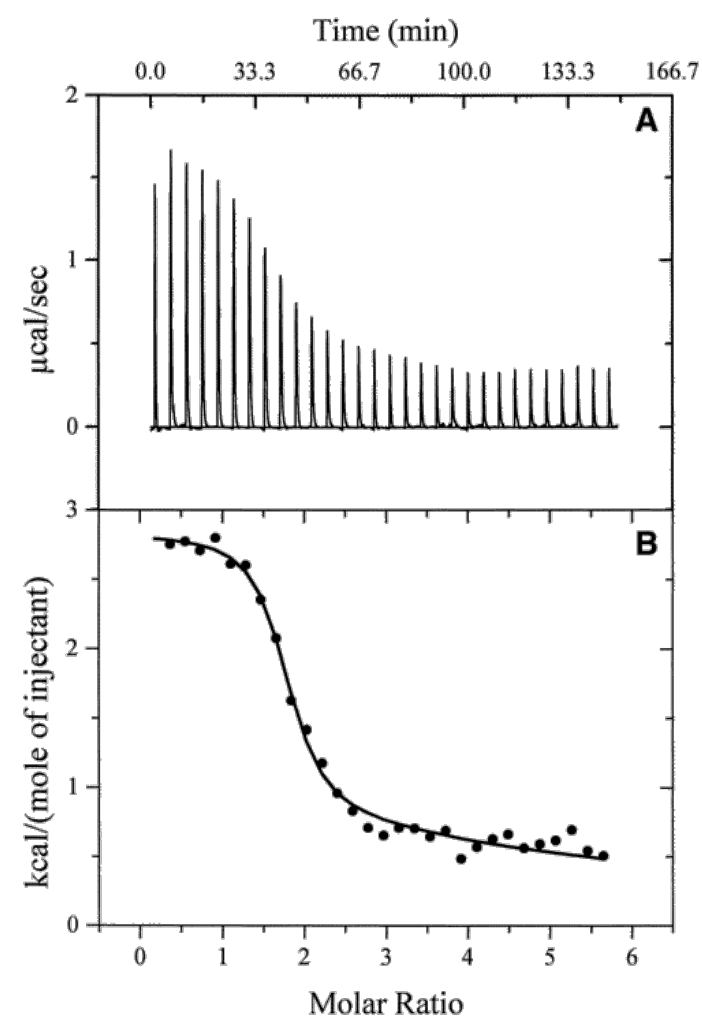

Figure 4 ITC titration of a $70 \mu \mathrm{M}$ solution of EcMetAP-I with a $5 \mathrm{mM} \mathrm{Mn}$ (II) solution at $20^{\circ} \mathrm{C}$ in $25 \mathrm{mM}$ Hepes buffer, $\mathrm{pH} 7.5$, and $150 \mathrm{mM} \mathrm{KCl}$.

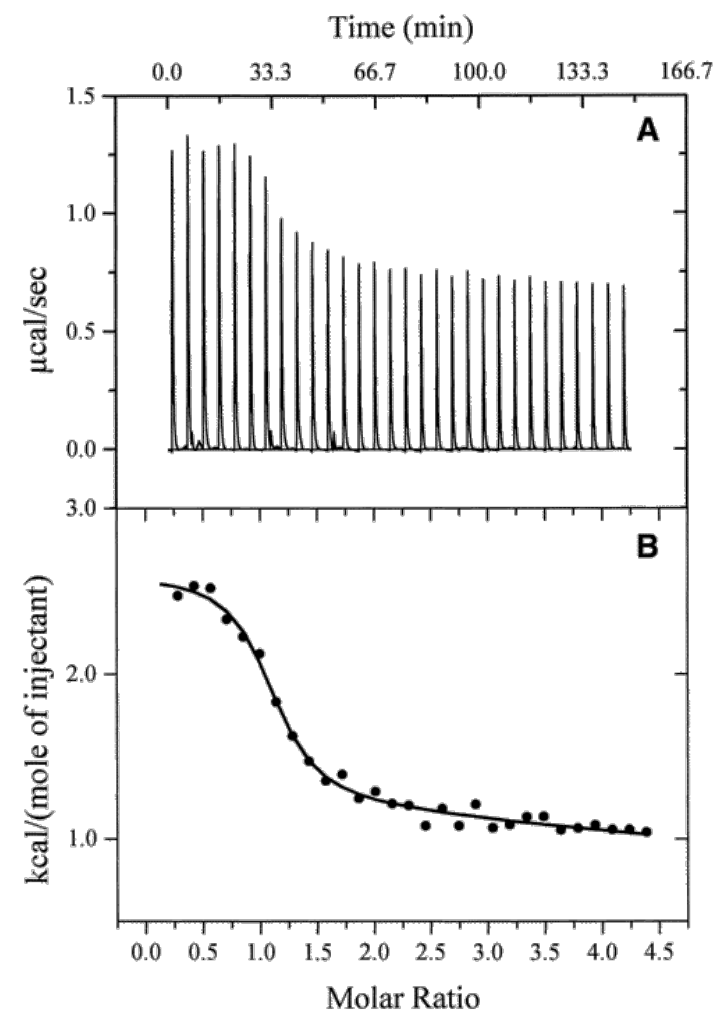

Figure 5 ITC titration of a $70 \mu \mathrm{M}$ solution of PfMetAP-II with a $5 \mathrm{mM} \mathrm{Mn}$ (II) solution at $30^{\circ} \mathrm{C}$ in $25 \mathrm{mM}$ Hepes buffer, $\mathrm{pH} 7.5$, and $150 \mathrm{mM} \mathrm{KCl}$. 
Temperature Dependence of the Hydrolysis of MGMM by Mn(II)-Loaded PfMetAP-II. Mn(II)-loaded PfMetAP-II was found to have optimal catalytic activity toward MGMM at $85^{\circ} \mathrm{C}$ in $25 \mathrm{mM}$ Hepes, $\mathrm{pH} 7.5$, and $150 \mathrm{mM} \mathrm{KCl}$ buffer. Therefore, hydrolysis of MGMM was measured in triplicate between 25 and 85 ${ }^{\circ} \mathrm{C}$ at eight substrate concentrations ranging from 2 to $20 \mathrm{mM}$. From these data, $K_{\mathrm{m}}$ values were derived by fitting the experimental data to the Michaelis-Menten equation at each temperature studied (Figure 6B). The calculated specific activity values were plotted as a function of temperature between 25 and $85^{\circ} \mathrm{C}$ (Figure $6 \mathrm{~A}$ ). The $K_{\mathrm{m}}$ and specific activity values for MGMM hydrolysis catalyzed by $\mathrm{Mn}$ (II)-loaded PfMetAP-II were found to increase with increasing temperature. PfMetAP-II was stable at $85^{\circ} \mathrm{C}$ for approximately 30 min before any loss in the enzymatic activity was detected. However, any loss in enzymatic activity was fully reversible, determined by $V_{\max }$, for temperatures up to $70^{\circ} \mathrm{C}$. These data are very unusual since most enzymes undergo some denaturation at temperatures above $50^{\circ} \mathrm{C}$ resulting in a decrease in $V_{\max }(25)$.
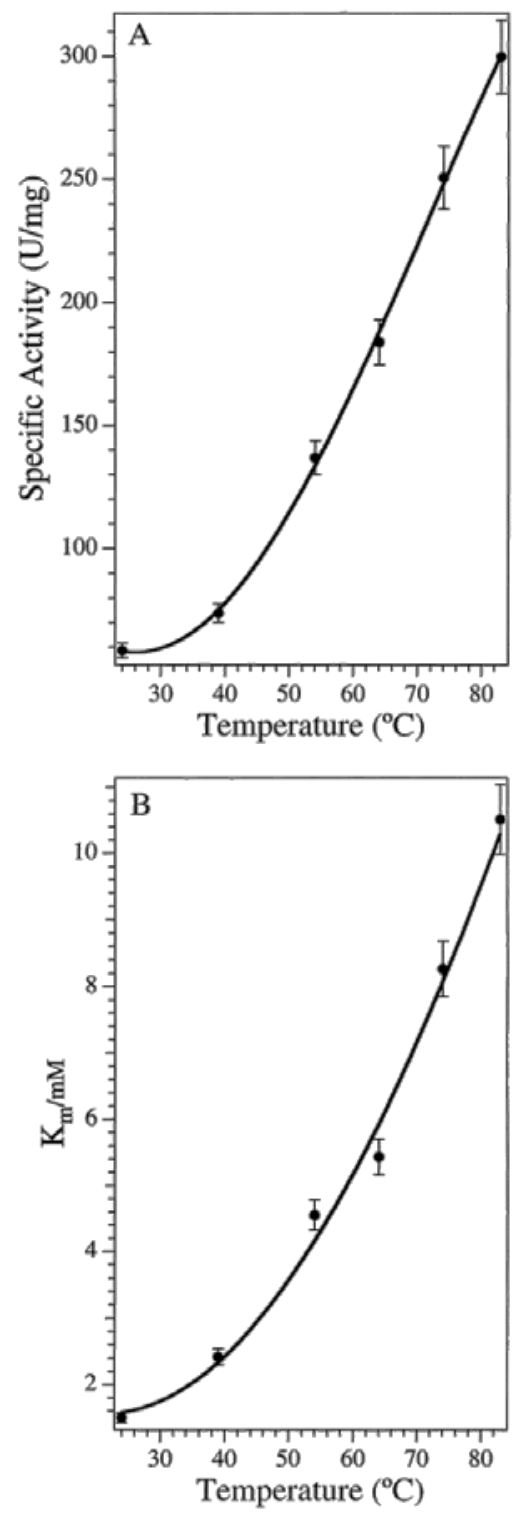

Figure 6 (A) Plot of specific activity (units/mg) of Mn(II)-loaded (·) PfMetAP-II vs temperature between 25 and 85 ${ }^{\circ} \mathrm{C}$. Each data point is the sum of three activity measurements at pH 7.5 in $25 \mathrm{mM}$ Hepes buffer and $150 \mathrm{mM} \mathrm{KCl}$ at substrate concentrations ranging from 2 to $20 \mathrm{mM}$. (B) $K_{\mathrm{m}}$ vs temperature $\left({ }^{\circ} \mathrm{C}\right)$. 
Since the enzyme concentration was not altered over the course of the experiment, an Arrhenius plot was constructed by plotting $\ln k_{\text {cat }}$ vs $1 / T$ (Figure 7). A linear plot was obtained, indicating that the rate-limiting step does not change as the temperature is increased (25). From the slope of the line the activation energy, $E_{a}$, for temperatures between 296 and $358 \mathrm{~K}$ was calculated to be $25.7 \mathrm{~kJ} / \mathrm{mol}$ for $\mathrm{Mn}$ (II)-loaded PfMetAP-II. Since the slope of an Arrhenius plot is equal to $-E_{\mathrm{a} 1} / R$, where $R=8.3145 \mathrm{~J} \cdot \mathrm{K}^{-1} \cdot \mathrm{mol}^{-1}$, other thermodynamic parameters were calculated by the relations $\Delta G^{\ddagger}=-R T \ln \left(k_{\text {cat }} h / k_{\mathrm{B}} T\right), \Delta H^{\ddagger}=E_{\mathrm{a}}-R T$, and $\Delta S^{\ddagger}=\left(\Delta H^{\ddagger}-\Delta G^{\ddagger}\right) / T$, where $k_{\mathrm{B}}, h$, and $R$ are the Boltzmann, Planck, and gas constants, respectively, and were found to be $\Delta G^{\ddagger}=50.1 \mathrm{~kJ} / \mathrm{mol}, \Delta H^{\ddagger}=$ $23.2 \mathrm{~kJ} / \mathrm{mol}$, and $\Delta S^{\ddagger}=-90.2 \mathrm{~J} \cdot \mathrm{mol}^{-1} \cdot \mathrm{K}^{-1}$.

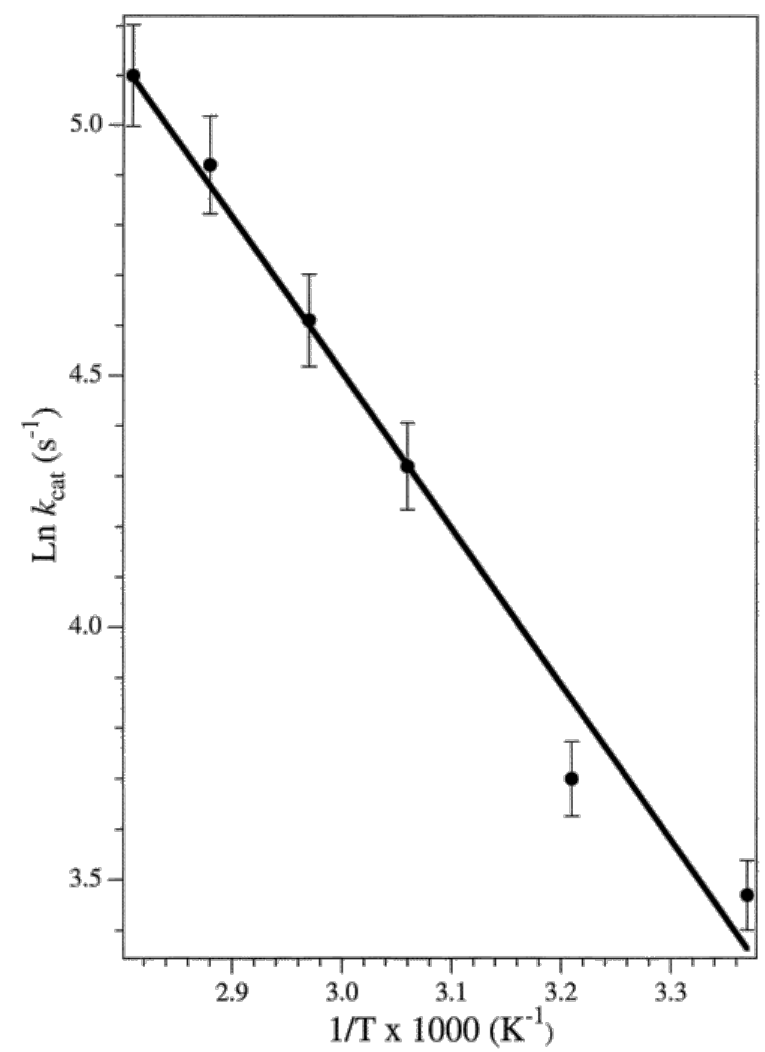

Figure 7 Arrhenius plot of $\ln k_{\text {cat }}$ vs $1 / T$ for $\mathrm{Mn}(\mathrm{II})$-loaded (·) PfMetAP-II. The solid line is a direct fit to the Arrhenius equation.

\section{X-ray Absorption Spectroscopy of EcMetAP-I.}

Manganese K-edge X-ray absorption (XAS) spectra were acquired on $1 \mathrm{mM}$ samples of EcMetAP-I with 1 or 2 equiv of added Mn(II) (i.e., [Mn(II)_(EcMetAP-I)] and [Mn(II)Mn(II)(EcMetAP-I)]). For [Mn(II)Mn(II)(EcMetAP-I)], the EXAFS data reveal an average of both metal ion environments. The $1 \mathrm{~s} \rightarrow 3 \mathrm{~d}$ preedge transitions for each sample occur at $6540 \mathrm{eV}$ (Figure 8). Since $1 \mathrm{~s} \rightarrow 3 \mathrm{~d}$ preedge transitions are Laporte forbidden in centrosymmetric environments (e.g., octahedral but not tetrahedral), the intensity of the $1 \mathrm{~s} \rightarrow 3 \mathrm{~d}$ preedge transition is inversely proportional to coordination number. The intensities of the observed transitions for all three samples are consistent with, on average, five- or six-coordinate $\mathrm{Mn}$ (II) sites. 


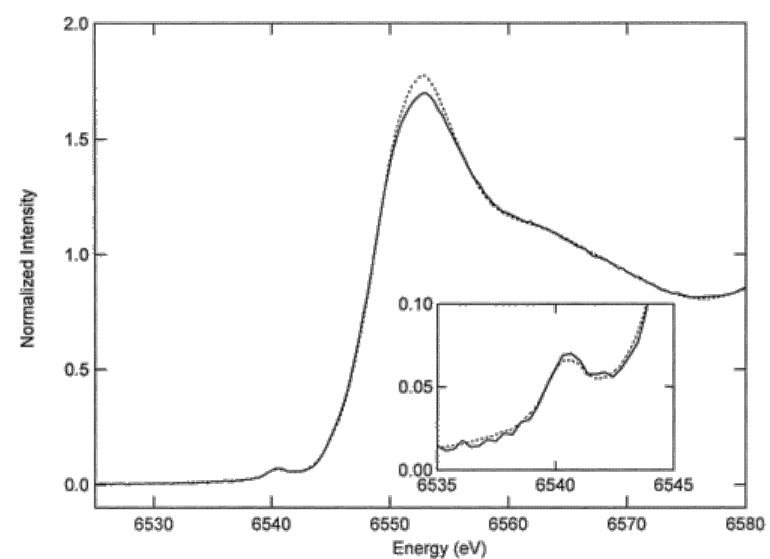

Figure $8 \mathrm{X}$-ray absorption K-edge spectra for EcMetAP-I: [Mn(II)_(EcMetAP-I)] (solid) and [Mn(II)Mn(II)(EcMetAP-I)] (dotted). In the inset, the preedge $1 \mathrm{~s} \rightarrow 3 \mathrm{~d}$ transition is expanded.

Fourier transforms (FTs) of the EXAFS data for both samples are dominated by a peak at ca. $2.1 \AA$ (Figure 9, bottom). Excellent single-shell fits of EXAFS spectra for both [Mn(II)_(EcMetAP-I)] and [Mn(II)Mn(II)(EcMetAP-I)] were obtained with 5 or $6 \mathrm{~N} / \mathrm{O}$ scatterers at 2.15 $\AA$ (fits 1-3 and 6-8; Table 3). Attempts to include a Mn-Mn interaction in the 2.4-4.0 ̊ range in the curve fitting parameters were unsuccessful. Inclusion of multiplescattering contributions from the outer-shell atoms of a histidine imidazole ring resulted in reasonable Debye-Waller factors and a slight reduction in the goodness-of-fit value ( $f^{\prime}$ ) for [Mn(II)_ (EcMetAP-I)] (cf. fits 2 and 4; Table 3). If a second histidine imidazole ring was included in fits for [Mn(II)_(ECMetAP-I)], the Debye-Waller factor values are significantly higher (fit 5; Table 3). For [Mn(II)Mn(II)(EcMetAP-I)], inclusion of a single outer-shell histidine scatterer resulted in a Debye-Waller factor that is similar in magnitude to those obtained with two outer-shell histidine scatterers for [Mn(II)_ (EcMetAP-I)] (cf. fits 4, 5, and 9; Table 3). The Debye-Waller factor values are significantly higher for [Mn(II)Mn(II)(EcMetAP-I)] than [Mn(II)_(EcMetAP-I)], consistent with the first $\mathrm{Mn}(\mathrm{II})$ ion binding to the histidine-containing site. 

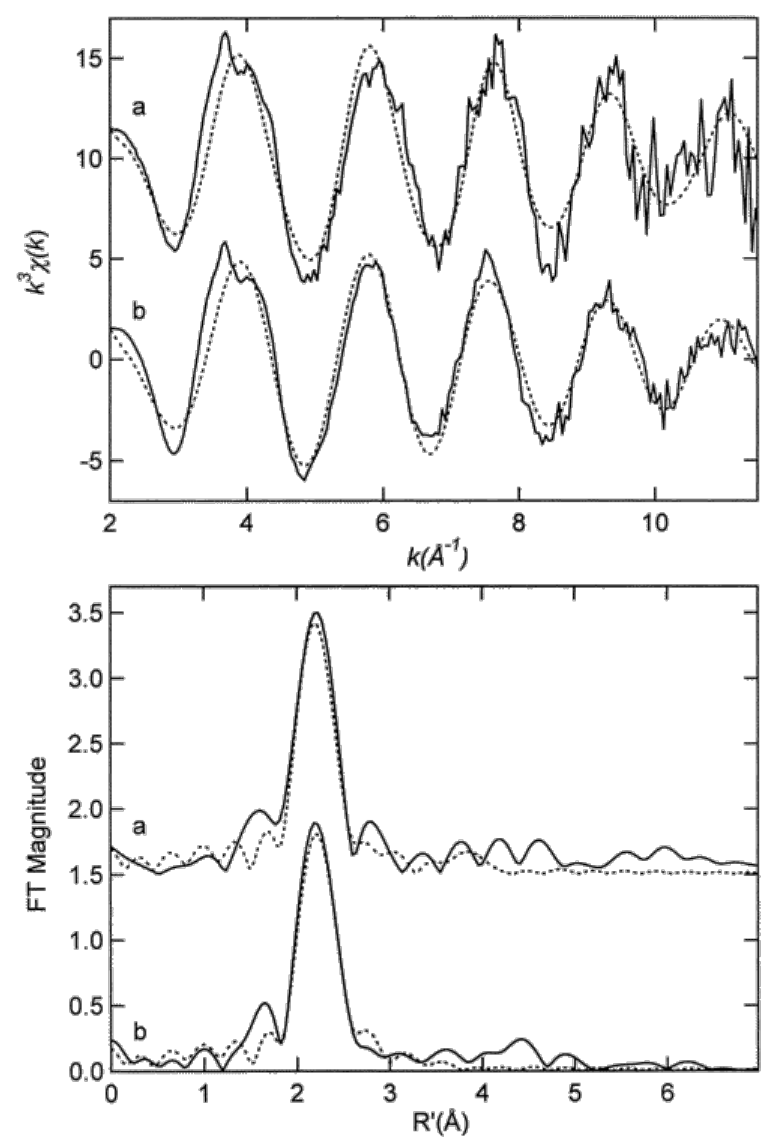

Figure $9 k^{3}$-weighted Mn EXAFS (top) and Fourier transforms (bottom, over $k=2-11.5 \AA^{-1}$ ) for [Mn(II)_(EcMetAP)] (a; solid) and the calculated spectra for $\mathrm{Mn}_{-} \mathrm{O}_{5}$ (imid) (dotted; fit 4, Table 2) and for

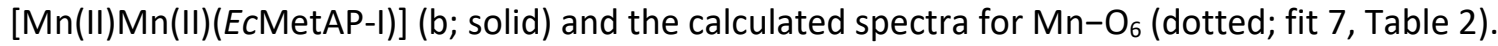

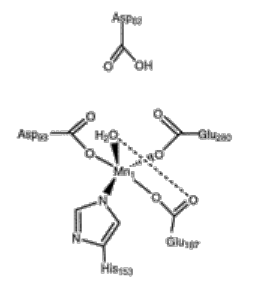

[Mn_(PfMetAP-II)]

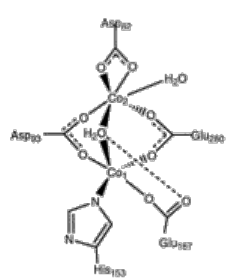

[CoCo(PfMetAP-In]

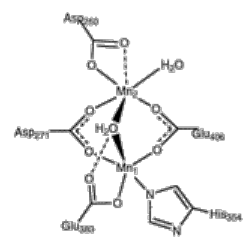

[MnMn(EcAMPP)]

Figure 10 Drawing of the proposed active site of Mn(II)-loaded PfMetAP-II or EcMetAP-I compared to the X-ray crystallographically characterized dicobalt form of PfMetAP-II and the dimanganese form of aminopeptidase $P$ from E. coli.

Table 3: Curve Fitting Results for Mn-Loaded EcMetAP-I EXAFS ${ }^{a}$

\begin{tabular}{|l|l|l|l|l|l|l|}
\hline sample & fit & shell & $R_{\text {as }}(\AA)$ & $\sigma_{\text {as }}{ }^{2}\left(\AA^{2}\right)$ & $\Delta E_{0}(\mathrm{eV})$ & $f^{\prime b}$ \\
\hline$\left[\mathrm{Mn}(\mathrm{II}) \_(E c M e t A P-\mathrm{I})\right]$ & 1 & $\mathrm{Mn}-\mathrm{O}_{5}$ & 2.15 & 0.0044 & -1.32 & 0.120 \\
\hline $\mathrm{MM} 20 \mathrm{~A}\left(2-11.5 \AA^{-1}\right)$ & 2 & $\mathrm{Mn}-\mathrm{O}_{6}$ & 2.15 & 0.0058 & -1.68 & 0.114 \\
\hline$\Delta k^{3} \chi=12.26$ & 3 & $\mathrm{Mn}-\mathrm{O}_{7}$ & 2.15 & 0.0071 & -1.94 & 0.113 \\
\hline & 4 & $\mathrm{Mn}-(\mathrm{O}, \mathrm{N})_{6}$ & 2.15 & 0.0058 & -1.89 & 0.111 \\
\hline & & $\mathrm{Mn}-\mathrm{C}_{\text {imid }}$ & 2.91 & 0.0036 & & \\
\hline & & $\mathrm{Mn}-\mathrm{C}_{\text {imid }}$ & {$[3.01]$} & {$[0.0037]$} & & \\
\hline & & $\mathrm{Mn}-\mathrm{N}_{\text {imid }}$ & {$[3.98]$} & {$[0.0049]$} & & \\
\hline & & $\mathrm{Mn}-\mathrm{C}_{\text {imid }}$ & {$[4.03]$} & {$[0.0049]$} & & \\
\hline
\end{tabular}




\begin{tabular}{|l|l|l|l|l|l|l|}
\hline & 5 & $\mathrm{Mn}-(\mathrm{O}, \mathrm{N})_{6}$ & 2.15 & 0.0058 & -1.95 & 0.110 \\
\hline & & $\mathrm{Mn}-\left(\mathrm{C}_{\text {imid }}\right)_{2}$ & 2.93 & 0.0096 & & \\
\hline & & $\mathrm{Mn}-\left(\mathrm{C}_{\text {imid }}\right)_{2}$ & {$[3.02]$} & {$[0.0100]$} & & \\
\hline & & $\mathrm{Mn}-\left(\mathrm{N}_{\text {imid }}\right)_{2}$ & {$[4.00]$} & {$[0.0132]$} & & \\
\hline$[\mathrm{Mn}(\mathrm{II}) \mathrm{Mn}(\mathrm{II})(E c \mathrm{MetAP}-\mathrm{I})]$ & 6 & $\mathrm{Mn}-\left(\mathrm{C}_{\text {imid }}\right)_{2}$ & {$[4.06]$} & {$[0.0132]$} & & \\
\hline $\mathrm{MM} 22 \mathrm{~A}\left(2-11.5 \AA^{-1}\right)$ & 7 & $\mathrm{Mn}-\mathrm{O}_{6}$ & 2.16 & 0.0047 & -1.51 & 0.082 \\
\hline$\Delta k^{3} \chi=11.82$ & 8 & $\mathrm{Mn}-\mathrm{O}_{7}$ & 2.16 & 0.0062 & -1.61 & 0.075 \\
\hline & 9 & $\mathrm{Mn}-(\mathrm{O}, \mathrm{N})_{6}$ & 2.16 & 0.0062 & -1.57 & 0.071 \\
\hline & & $\mathrm{Mn}-\mathrm{C}_{\text {imid }}$ & 2.97 & 0.0095 & & \\
\hline & & $\mathrm{Mn}-\mathrm{C}_{\text {imid }}$ & {$[3.07]$} & {$[0.0099]$} & & \\
\hline & & $\mathrm{Mn}-\mathrm{N}_{\text {imid }}$ & {$[4.05]$} & {$[0.0131]$} & & \\
\hline & & $\mathrm{Mn}-\mathrm{C}_{\text {imid }}$ & {$[4.11]$} & {$[0.0131]$} & & \\
\hline
\end{tabular}

a Group is the chemical unit defined for the multiple scattering calculation. Ns is the number of scatterers (or groups) per metal. Ras is the metal-scatterer distance. oas2 is a mean square deviation in Ras. $\Delta \mathrm{E} 0$ is the shift in $\mathrm{EO}$ for the theoretical scattering functions. Numbers in brackets were constrained either to be a multiple of the above value (oas2) or to maintain a constant difference from the above value (Ras, $\triangle E 0$ ). $b f^{\prime}{ }^{\prime}$ is defined as

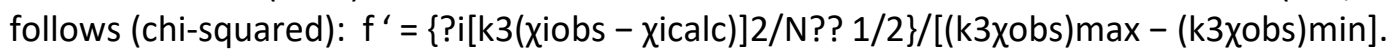

\section{Discussion}

Until recently, all MetAP's studied have been reported to be Co(II)-dependent metalloproteases $(16,17)$. This conclusion was arrived at from the reproducible observations that MetAP's show high activity in the presence of $\mathrm{Co}(\mathrm{II})$ when compared to the activity levels of other divalent metal ions such as $\mathrm{Zn}(\mathrm{II}), \mathrm{CU}(\mathrm{II})$, or Ni(II). However, in all in vitro studies to date, Co(II) concentrations were artificially inflated to the millimolar range during purification. Walker and Bradshaw were the first to suggest that MetAP's could be activated by Zn(II) ions on the basis of activity measurements made on the type I MetAP from S. cerevisiae (26); however, EcMetAP-I and more recently PfMetAP-I and HsMetAP-II were shown to be inactive in the presence of $\mathrm{Zn}(\mathrm{II})$, but each of these enzymes is fully active in the presence of 1 equiv of Co(II) while EcMetAP-I and PfMetAP-II are equally as active in the presence of 1 equiv of Fe(II) (18). On the other hand, EcMetAP-I was found to retain $30 \%$ of the observed $\mathrm{Co}$ (II) activity in the presence of excess $\mathrm{Mn}$ (II) (18). Iron, manganese, and zinc, unlike cobalt, are abundant in nature and have many known biological roles (27). The question of what type and how many divalent metal ions are required to activate MetAP's is of particular importance since MetAP's are currently under heavy investigation as antiangiogenesis targets for anticancer drugs. To design and synthesize small molecule drug candidates with nanomolar or picomolar binding constants to MetAP's, the number, geometry, and type of in vivo metal ions must be elucidated.

The evidence suggesting that a single Fe(II) ion is required to activate all MetAP's is growing but has yet to be unequivocally proven. Since $\mathrm{Mn}(\mathrm{II})$ ions can also activate MetAP's, we have investigated the enzymatic activity of Mn(II)-loaded EcMetAP-I and PfMetAP-II. Activity measurements as a function of added Mn(II) show that both ECMetAP-I and PfMetAP-II are maximally stimulated upon the addition of 2 equiv of metal ion. The addition of up to 400 equiv of $\mathrm{Mn}$ (II) did not significantly change the observed catalytic activity levels. In addition, ICPAES analyses of $30 \mu \mathrm{M} \mathrm{Mn}$ (II)-loaded EcMetAP-I and PfMetAP-II samples that had been extensively dialyzed against metal-free buffer routinely indicated that 1.3 and 1.5 equiv of divalent metal ions are tightly bound per enzyme molecule to EcMetAP-I and PfMetAP-II, respectively. These data suggest that at least one Mn(II) ion is tightly bound to both enzymes while a second is more weakly bound and likely in equilibrium between a metalbound and unbound form at these enzyme concentrations $(\sim 8 \mu \mathrm{M})$. Moreover, these data indicate that the monometal form of EcMetAP-I and PfMetAP-II is catalytically competent. To determine if a dinuclear site is 
formed at an enzyme concentration of $\sim 8 \mu \mathrm{M}$, the metal binding constants for both metal binding events were determined.

Fits of the titration data obtained for both EcMetAP-I and PfMetAP-II with Mn(II) ions provided dissociation constants $\left(K_{\mathrm{d}}\right)$ for the first metal binding site of 6 and $1 \mu \mathrm{M}$, respectively. Since only one metal ion is bound to the enzyme active site, these $K_{d}$ values correspond to the microscopic binding constants for the binding of a single metal ion to ECMetAP-I and PfMetAP-II. Confirmation of these $K_{\mathrm{d}}$ values was obtained from isothermal titration calorimetry (ITC), which provided $K_{d}$ values of 4.4 and $1.3 \mu \mathrm{M}$ for $\mathrm{Mn}$ (II) binding to EcMetAP-I and PfMetAP-II, respectively. Further, the ITC data indicated that two additional $\mathrm{Mn}$ (II) ions can bind to both EcMetAP-I and PfMetAP-II with $K_{d}$ values of 4400 and $500 \mu \mathrm{M}$, respectively. A second Co(II) ion has been shown to bind to ECMetAP-I and PfMetAP-II with $K_{\mathrm{d}}$ values of 2500 and $500 \mu \mathrm{M}$, respectively. Moreover, a third Co(II) ion binding site was identified in the X-ray crystal structure of EcMetAP-I (11). On the basis of these data and those presented herein, only one $\mathrm{Mn}(\mathrm{II})$ ion is tightly bound to either EcMetAP-I or PfMetAP-II, and thus only one $\mathrm{Mn}(\mathrm{II})$ ion is needed to activate either enzyme. The fact that the catalytic activity does not plateau until more than 2 equiv of $\mathrm{Mn}(\mathrm{II})$ are added is because the $K_{\mathrm{d}}$ values for the first metal binding event is on the order of the enzyme concentration used in the experiment. Our data also suggest that the putative second metal ion in the active site of MetAP's and the third metal binding site have similar metal binding affinities.

The $K_{\mathrm{d}}$ values obtained for $\mathrm{Mn}(\mathrm{II})$ binding to EcMetAP-I and PfMetAP-II are somewhat weaker than those observed for Co(II) or Fe(II) EcMetAP-I and PfMetAP-II. For EcMetAP-I and PfMetAP-II, the $K_{d}$ values for Co(II) binding were 300 and $50 \mathrm{nM}$ while those for Fe(II) binding were 200 and $20 \mathrm{nM}$, respectively (15). The $K_{\mathrm{d}}$ values observed for $\mathrm{Mn}$ (II) binding to either EcMetAP-I or PfMetAP-II are approximately a factor of 5 weaker than $\mathrm{Co}$ (II) or Fe(II) binding to either enzyme. The observed $K_{d}$ values for the first $\mathrm{Mn}(\mathrm{II})$ binding event to either EcMetAP-I or PfMetAP-II are also 10-100 times larger than the reported $K_{\mathrm{d}}$ values for several other hydrolytic enzymes that contain carboxylate-rich active sites. For example, the $K_{\mathrm{d}}$ values for the first metal binding site of the aminopeptidase from Aeromonas proteolytica is $1 \mathrm{nM}(28)$, and the $\beta$-lactamase from Bacillus cereus has a divalent metal ion $K_{\mathrm{d}}$ value of $620 \mathrm{nM}$ (29). On the other hand, the observed $K_{\mathrm{d}}$ values for $\mathrm{Mn}(\mathrm{II})$ binding to EcMetAP-I or PfMetAP-II are similar in magnitude to the $K_{\mathrm{d}}$ value reported for the $\mathrm{Mn}$ (II)-dependent clostridial aminopeptidase $\mathrm{P}$ (AMPP) of $7 \mu \mathrm{M}$, which has active site ligands identical to those of MetAP's (30).

Since PfMetAP-II is stable at $75^{\circ} \mathrm{C}$ for $1 \mathrm{~h}$, PfMetAP-II provides the unique opportunity to determine the activation parameters of the $\mathrm{ES}^{\ddagger}$ complex over a wide temperature range. Construction of an Arrhenius plot from the temperature dependence of $\mathrm{Mn}$ (II)-loaded PfMetAP-II activity indicates that the rate-limiting step does not change as a function of temperature and is product release (25). This finding is similar to that obtained for Co(II)- and Fe(II)-loaded PfMetAP-II (14). The activation energy $\left(E_{\mathrm{a}}\right)$ for the activated $\mathrm{ES}^{\ddagger}$ complex is $25.7 \mathrm{~kJ} / \mathrm{mol}$, which is nearly double the value obtained for either Co(II)- and Fe(II)-loaded PfMetAP-II (14). The enthalpy of activation calculated over the temperature range $25-85^{\circ} \mathrm{C}$ is $23.2 \mathrm{~kJ} / \mathrm{mol}$ while the entropy of activation was found to be $-90.2 \mathrm{~J} \cdot \mathrm{mol}^{-1} \cdot \mathrm{K}^{-1}$ at $25^{\circ} \mathrm{C}$. The positive enthalpy is indicative of a conformation change upon substrate binding, likely due to the energy of bond formation and breaking during nucleophilic attack on the scissile carbonyl carbon of the substrate. On the other hand, the large negative entropy value suggests that some of the molecular motions are lost upon $\mathrm{ES}^{\ddagger}$ complex formation possibly due to hydrogen bond formation between catalytically important amino acids and the substrate. All of these factors contribute to the large positive free energy of activation of $50.1 \mathrm{~kJ} / \mathrm{mol}$. Interestingly, the observed specific activity of $\mathrm{Mn}$ (II)loaded PfMetAP-II increases from $\sim 60$ to 300 units/mg between 25 and $85^{\circ} \mathrm{C}$. The specific activity observed for $\mathrm{Mn}$ (II)-loaded PfMetAP-II at $85^{\circ} \mathrm{C}$ is roughly equal to the specific activity of Co(II)- and Fe(II)-loaded PfMetAP-II at $25^{\circ} \mathrm{C}$ but is still $\sim 3$ times lower than the activity levels obtained at $85^{\circ} \mathrm{C}$. However, the $K_{\mathrm{m}}$ value for $\mathrm{Mn}(\mathrm{II})-$ loaded PfMetAP-II also increases to over $10 \mathrm{mM}$ at $85^{\circ} \mathrm{C}$ so the catalytic efficiency of $\mathrm{Mn}$ (II)-loaded PfMetAP-II does not change significantly over this temperature range. On the basis of these data, Fe(II)-loaded PfMetAP-II is 
a much better catalyst at the optimum growth temperature of $P$. furiosus $\left(85^{\circ} \mathrm{C}\right.$ ) than either $\mathrm{Co}$ (II)- or $\mathrm{Mn}$ (II)loaded PfMetAP-II (14). These data further suggest that Fe(II) is the physiologically relevant metal ion.

Since Mn(II)-loaded EcMetAP-I and PfMetAP-II are colorless and no X-ray structural data have been reported, the structural aspects of these catalytically competent MetAP enzymes are unknown. Therefore, extended X-ray absorption fine structure (EXAFS) data were recorded on [Mn(II)_(EcMetAP-I)] and [Mn(II)Mn(II)(ECMetAP-I)] and provide the first structural glimpse of the Mn(II) active sites of EcMetAP-I. The EXAFS data are consistent with the X-ray crystal structure of Co(II)-loaded EcMetAP-I, which indicates that the histidine-ligated Co(II) ion resides in a distorted trigonal-bipyramidal coordination environment made up of oxygen or nitrogen donor ligands while the second $\mathrm{Co}(\mathrm{II})$ ion is also trigonal bipyramidal $(12,31)$. The average bond distances obtained by EXAFS for both ECMetAP-I samples are in good agreement with the crystallographically determined bond lengths for [Co(II)Co(II)(ECMetAP-I)] of $2.04 \AA$ (12). Additionally, it was recently reported, on the basis of ${ }^{1} \mathrm{H}$ NMR data, that upon the addition of $\mathrm{Co}$ (II) to EcMetAP-I, the first $\mathrm{Co}$ (II) is bound to the lone histidine residue in the active site (15). This is consistent with the suggestion of a single histidine ligand at the active site, based on crystallographic analyses. The Debye-Waller factor values for the $\mathrm{Mn}$-histidine interaction are significantly higher for [Mn(II)Mn(II)(ECMetAP-I)] than for [Mn(II)_(EcMetAP-I)], suggesting that the first $\mathrm{Mn}$ atom is located in the histidine-ligated site. Furthermore, the EXAFS data do not detect a Mn-Mn interaction similar to data obtained for [Co(II)Co(II)(ECMetAP-I)] and [Fe(II)Fe(II)(EcMetAP-I)] (19). These data indicate that a dinuclear $\mathrm{Mn}$ (II) site does not exist in EcMetAP-I, as seen in the published X-ray crystal structures for all Co(II)-loaded MetAP's $(11,12)$. The lack of a M-M FT peak in the second shell of [Mn(II)Mn(II)(EcMetAP-I)] is consistent with a single $\mathrm{Mn}(\mathrm{II})$ ion being capable of activating MetAP's and is also in line with the metal binding constants reported herein.

Biological and Mechanistic Implications. According to the recently proposed mechanism for the aminopeptidase from A. proteolytica (AAP), substrate binding to the hydrophobic pocket adjacent to the dinuclear active site is the first step in catalysis (32). Since a hydrophobic pocket is also adjacent to the metallo active site in all MetAP's, the first step in catalysis for MetAP's is likely similar to AAP. When substrate (MGMM) binds to MetAP, the carbonyl oxygen of the $\mathrm{N}$-terminal methionine must be activated, probably by binding to the active site metal ion (31). Once carbonyl activation occurs, the nucleophilic hydroxide must be oriented correctly for attack on the scissile carbonyl carbon. For Zn(II)-loaded EcMetAP-I and PfMetAP-II, the correct positioning of the scissile carbonyl carbon must not occur for catalytic turnover since each of these enzymes is inactive in the presence of $\mathrm{Zn}(\mathrm{II})$. This may simply be the result of a trigonal-bipyramidal (TBP) geometry for $\mathrm{Co}(\mathrm{II}), \mathrm{Fe}(\mathrm{II})$, and $\mathrm{Mn}$ (II) bound in the first site of MetAP's vs a tetrahedral $\left(\mathrm{T}_{\mathrm{d}}\right)$ or trigonal planar geometry if $\mathrm{Zn}(\mathrm{II})$ were bound instead (unpublished results). The proposal that $\mathrm{Zn}$ (II) prefers a $\mathrm{T}_{\mathrm{d}}$ geometry comes from the ligand field stabilization energies (LFSE's) for octahedral $\left(\mathrm{O}_{h}\right), \mathrm{T}_{d}$, or trigonal planar geometries of $\mathrm{Zn}(\mathrm{II})$ and the observed Xray crystal structure of $\mathrm{Zn}$ (II)-loaded PfMetAP-II (unpublished results) and Zn(II) model complexes with mixed $\mathrm{O} / \mathrm{N}$ ligands. For both $\mathrm{O}_{h}$ and $\mathrm{T}_{d}$ geometries, the LFSE's are zero, suggesting that neither structure is favored. However, on the basis of X-ray crystallographic data, $\mathrm{Zn}$ (II) clearly favors a $T_{d}$ geometry (33). The reason for this is that the $4 \mathrm{~s}$ and $4 \mathrm{p}$ orbitals are easily accessible as electron pair acceptors, providing an $\mathrm{sp}^{3}$-type center, while the $4 \mathrm{~d}$ orbitals are higher in energy, making the formation of $\mathrm{O}_{h}$ or trigonal-bipyramidal (TBP) complexes less favorable.

Another factor that might be involved in the catalytic process is the change in Lewis acidity between Co(II), $\mathrm{Fe}(\mathrm{II})$, or $\mathrm{Mn}(\mathrm{II})$ vs $\mathrm{Zn}(\mathrm{II})$. The effect of Lewis acidity on the reaction catalyzed by MetAP's can be gleaned from the $k_{\text {cat }} / K_{\mathrm{m}}$ values for $\mathrm{Mn}(\mathrm{II})-$-, Fe(II)-, and Co(II)-loaded forms of MetAP's determined at $30{ }^{\circ} \mathrm{C}$. Toward the substrate MGMM, the $k_{\text {cat }} / K_{\mathrm{m}}$ values are 20800,36900 , and $30600 \mathrm{M}^{-1} \mathrm{~s}^{-1}$ for $\mathrm{Mn}(\mathrm{II})-$, $\mathrm{Fe}(\mathrm{II})$-, and $\mathrm{Co}(\mathrm{II})$ loaded PfMetAP-II, respectively, and for Mn(II)-, Fe(II)-, and Co(II)-loaded EcMetAP-I the $k_{\text {cat }} / K_{\mathrm{m}}$ values are 3500, 13700 , and $12100 \mathrm{M}^{-1} \mathrm{~s}^{-1}$, respectively. These observations are consistent with the fact that $\mathrm{Mn}(\mathrm{II})$ is a harder 
acid than either $\mathrm{Fe}(\mathrm{II})$ or $\mathrm{Co}(\mathrm{II})$; however, the $k_{\mathrm{cat}} / K_{\mathrm{m}}$ values do not change markedly with regard to the metal ion in the active site. Therefore, these data suggest that Lewis acidity is not the major factor for catalytic turnover to occur.

The proposal that a TBP geometry for the catalytic metal ion in the active site of MetAP's is required is also supported by the fact that when $\mathrm{CU}(\mathrm{II})$ is substituted into EcMetAP-I, it resides in a square-based pyramidal (SP) geometry, and the resulting enzyme is inactive. Moreover, Ni(II) cannot activate MetAP's, but for Ni(II), an $\mathrm{O}_{h}$ geometry is significantly favored over $\mathrm{T}_{d}$ or TBP geometries on the basis of LFSE's. These data, coupled with the fact that the vast majority of metalloproteases can be activated by every first row transition metal ion from $\mathrm{Co}(\mathrm{II})$ to $\mathrm{Zn}$ (II), suggest that the Lewis acidity of the metal ion bound in the active site of MetAP's is less important than the coordination geometry that the hydrolytic metal ion, M1, adopts. The geometrical importance of the catalytic metal ion in MetAP's is likely widely applicable to hydrolytic metalloenzymes with both mono- and dinuclear active sites. Thus, metal ion geometry is critical for the activated substrate and for the nucleophile to be positioned correctly for catalytic turnover to occur while Lewis acidity likely plays a secondary role to metal ion geometry.

\section{References}

1 Bradshaw, R. A. (1989) Trends Biochem. Sci.14, 276-279.

2 Meinnel, T., Mechulam, Y., and Blanquet, S. (1993) Biochimie75, 1061-1075.

3 Bradshaw, R. A., Brickey, W. W., and Walker, K. W. (1998) Trends Biochem. Sci.23, 263-267.

4 Arfin, S. M., and Bradshaw, R. A. (1988) Biochemistry27, 7979-7984.

5 Hirel, P.-H., Schmitter, J.-M., Dessen, P., Fayat, G., and Blanquet, S. (1989) Proc. Natl. Acad. Sci. U.S.A.86, 8247-8251.

6 Ben-Bassat, A., Bauer, K., Chang, S.-Y., Myambo, K., Boosman, A., and Chang, S. (1987) J. Bacteriol.169, 751-757.

7 Chang, S.-Y. P., McGary, E. C., and Chang, S. (1989) J. Bacteriol.171, 4071-4072.

8 Miller, C. G., Kukral, A. M., Miller, J. L., and Movva, N. R. (1989) J. Bacteriol.171, 5215-5217.

9 Li, X., and Chang, Y.-H. (1995) Proc. Natl. Acad. Sci. U.S.A.92, 12357-12361.

10 Tahirov, T. H., Oki, H., Tsukihara, T., Ogasahara, K., Yutani, K., Ogata, K., Izu, Y., Tsunasawa, S., and Kato, I. (1998) J. Mol. Biol.284, 101-124.

11 Lowther, W. T., Orville, A. M., Madden, D. T., Lim, S., Rich, D. H., and Matthews, B. W. (1999) Biochemistry38, 7678-7688.

12 Roderick, S. L., and Matthews, B. W. (1993) Biochemistry32, 3907-3912.

13 Liu, S., Widom, J., Kemp, C. W., Crews, C. M., and Clardy, J. (1998) Science282, 1324-1327.

14 Meng, L., Ruebush, S., D'souza, V. M., Copik, A. J., Tsunasawa, S., and Holz, R. C. (2002) Biochemistry41 (in press).

15 D'souza, V. M., Bennett, B., Copik, A. J., and Holz, R. C. (2000) Biochemistry39, 3817-3826.

16 Barrett, A. J., Rawlings, N. D., and Woessner, J. F. (1998) pp 1-1666, Academic Press, London.

17 Taylor, A. (1996) in Molecular Biology Intelligence Unit (A., T., Ed.) pp 1-219, R. G. Landes Co., Austin, TX.

18 D'souza, V. M., and Holz, R. C. (1999) Biochemistry38, 11079-11085.

19 Cosper, N. J., D'souza, V., Scott, R., and Holz, R. C. (2001) Biochemistry40, 13302-13309.

20 Lowther, W. T., McMillen, D. A., Orville, A. M., and Matthews, B. W. (1998) Proc. Natl. Acad. Sci. U.S.A.95, $12153-12157$.

21 Scott, R. A. (1985) Methods Enzymol.117, 414-458.

22 Cosper, N. J., Stalhandske, C. M. V., Saari, R. E., Hausinger, R. P., and Scott, R. A. (1999) J. Biol. Inorg. Chem.4, 122-129.

23 Zabinski, S. I., Rehr, J. J., Ankudinov, A., Albers, R. C., and Eller, M. (1995) J. Phys. Rev. B11, 305.

24 Garrett, T. P. J., Guss, J. M., and Freeman, H. C. (1983) Acta Crystallogr.39, 1027. 
25 Segel, I. H. (1975) Enzyme Kinetics: Behavior and analysis of rapid equilibrium and steady-state enzyme systems, 1st ed., John Wiley \& Sons, New York.

26 Walker, K. W., and Bradshaw, R. A. (1998) Protein Sci.7, 2684-2687.

27 Holm, R. H., Kennepohl, P., and Solomon, E. I. (1996) Chem. Rev.96, 2239-2314.

28 Prescott, J. M., and Wilkes, S. H. (1976) Methods Enzymol.45B, 530-543.

29 de Seny, D., Heinz, U., Wommer, S., Kiefer, M., Meyer-Klaucke, Galleni, M., Frere, J.-M., Bauer, R., and Adolph, H.-W. (2001) J. Biol. Chem.276, 45065-45078.

30 Fleminger, G., and Yaron, A. (1984) Biochim. Biophys. Acta789, 245-256.

31 Lowther, T. W., Zhang, Y., Sampson, P. B., Honek, J. F., and Matthews, B. W. (1999) Biochemistry38, 14810-14819.

32 Stamper, C., Bennett, B., Edwards, T., Holz, R. C., Ringe, D., and Petsko, G. (2001) Biochemistry40, 7034-7046.

33 Bertini, I., Luchinat, C., Rosi, M., Sgamellotti, A., and Tarantelli, F. (1990) Inorg. Chem.29, 1460-1463.

1Abbreviations: MetAP, methionyl aminopeptidase; Hepes, $N$-(2-hydroxyethyl)piperazine- $N$ '-2-ethanesulfonic acid; MAS, tripeptide Met-Ala-Ser; MGMM, tetrapeptide Met-Gly-Met-Met; EPR, electron paramagnetic resonance; EXAFS, extended X-ray absorption fine structure; XAS, X-ray absorption spectroscopy; ICPAES, inductively coupled plasma-atomic emission spectroscopy; NMR, nuclear magnetic resonance. 